\title{
Auditory Brainstem Response in Newborns with Hyperbilirubinemia
}

\author{
Yong Hee Cho, Jae Ho Oh, Dong Won Lee, Jae Ho Chung, Chul Won Park and Seung Hwan Lee \\ Department of Otolaryngology-Head and Neck Surgery, College of Medicine, Hanyang University, Seoul, Korea
}

\section{고빌리루빈혈증 환아에서 청성뇌간유발반응을 이용한 청력 고찰}

\author{
조용희 · 오재호 - 이동원 · 정재호 · 박철원 · 이승환 \\ 한양대학교 의과대학 이비인후-두경부외과학교실
}

\author{
Received May 23, 2013 \\ Revised June 29, 2013 \\ Accepted July 5, 2013 \\ Address for correspondence \\ Seung Hwan Lee, MD \\ Department of Otolaryngology- \\ Head and Neck Surgery, \\ College of Medicine, \\ Hanyang University, \\ 222 Wangsimni-ro, Seongdong-gu, \\ Seoul 133-792, Korea \\ Tel $+82-31-560-2363$ \\ Fax $+82-31-566-4884$ \\ E-mail shleemd@hanyang.ac.kr
}

Background and Objectives Neonatal hyperbilirubinemia is one of the important causative factors of sensorineural hearing loss including auditory neuropathy. The auditory brain stem response (ABR) is widely used as a screening or diagnostic tool for newborn hearing loss. This study aimed to analyze serial ABR results of newborns with severe hyperbilirubinemia. Subjects and Method This study examined 120 full term infants treated for hyperbilirubinemia in the neonatal intensive care unit. The first ABR was performed within one month after birth. Follow-up tests were conducted in patients with abnormal results ( 25 cases). The control group was composed of 21 healthy newborns who passed the newborn hearing screening. Results The mean ABR threshold was higher in the newborns with hyperbilirubinemia than in the control group ( $43.8 \mathrm{~dB}$ nHL versus $30.0 \mathrm{~dB}$ nHL, $p<0.001$ ). Of the 25 newborns who underwent follow-up ABR, 15 newborns demonstrated recovery of the hearing threshold up to $30 \mathrm{~dB} \mathrm{nHL}$. The hearing threshold did not improve below $50 \mathrm{~dB} \mathrm{nHL}$ for five newborns, of whom one was diagnosed with auditory neuropathy spectrum disorder. There was no difference in the mean ABR interwave latency between newborns with hyperbilirubinemia and the control group.

Conclusion Neonates with hyperbilirubimenia might suffer transient or permanent hearing loss. Serial ABR tests might be essential for the diagnosis of sensorineural hearing loss in patients with neonatal hyperbilirubinemia.

Korean J Otorhinolaryngol-Head Neck Surg 2013;56:490-4

Key Words Auditory brainstem response $\cdot$ Hearing loss $\cdot$ Neonatal jaundice.
서 론

신생아 감각신경성 난청은 발생률이 1000명당 1 3명 정도 로 발병률이 높은 질환이다. ${ }^{1,2)}$ 신생아집중치료실(neonatal intensive care unit)에서 치료를 받은 경우나 난청의 위험인 자를 가진 신생아에서 난청의 유병률은 2 5\% 정도까지 보고 되고 있으며 ${ }^{3)}$ 소아 감각신경성 난청의 $10 ~ 15 \%$ 는 청각신경병 증(auditory neuropathy spectrum disorder)으로 알려져 있 다.,5) 신생아 고빌리루빈혈증은 신생아집중치료실 치료를 받
게 되는 대표적인 원인이며, 청각신경병증의 중요한 위험 인자 로 알려져 있다. 최근 연구에서는 청신경병증을 가진 소아의 $50 \%$ 에서 고빌리루빈혈증과 연관이 있다고 보고되었다. ${ }^{6}$ 따 라서 신생아 고빌리루빈혈증을 경험한 환아에서 객관적인 청 력검사를 통해 정확한 청력을 평가하는 것은 매우 중요하다. ${ }^{7}$

청성뇌간유발반응(auditory brainstem-evoked response) 은 비침습적이고, 객관적인 검사이며, 검사 결과와 청력 역치 간의 상관관계가 높고 다른 기형이 동반되지 않은 만삭아의 경우 일반적으로 청성뇌간유발반응 검사 상 정상 소견을 보이 
기 때문에, 이음향방사(otoacoustic emissions)검사와 함께 신생아 청력 검사에 널리 사용된다.1) 그리고 청성뇌간유발반 응 검사는 청각 경로 및 뇌간의 신경학적 평가가 가능하므로, 청신경병증의 진단에 필수적인 검사이다.8)

본 연구에서는 고빌리루빈혈증 환아에서 연속적인 청성뇌 간유발반응 검사를 통해 청력 역치를 측정하고, 그 결과를 분 석하여 고빌리루빈혈증이 신생아의 청력 역치와 청각 경로에 미치는 영향을 알아보고자 하였다.

\section{대상 및 방법}

본 연구는 기관윤리심의위원회의 승인 후 2008년 3월부터 2012년 3월까지, 상급종합병원인 본원에서 시행한 신생아 청력 검사 결과를 바탕으로 후향적으로 분석하였다. 환자군은 제 태기간 37주 이상, 출생 체중 $2500 \mathrm{~g}$ 이상의 만삭 신생아 중, 고빌리루빈혈증의 치료를 위하여 신생아중환자실에 입원한 120 명의 환아를 대상으로 총 240 개의 귀를 검사하였다. 조산아, 두개안면기형, 아미노글리코사이드 계 항생제 노출, 난청의 가 족력, 주산기 가사 등 기타 난청의 위험 인자들이 있는 경우는 제외하였다. 검사 전 현미경 고막 검사를 통하여 중이 삼출액 여부를 확인하였다. 대조군은 청성뇌간유발반응 검사 상 정상 소견을 보인, 건강한 만삭 신생아 21명을 대상으로 하였다.

청성뇌간유발반응 검사는 출생 후 2 주안에 검사를 시행하 였으며, 모든 검사에서 진정제는 투여하지 않았다. 검사의 자극 음은 Click음을 이용하였고, 자극음의 극성은 교대상(alternating)을 사용하였다. 전위의 증폭기(amplifier)는 10만배 정 도로 반응을 증폭하여 기록하였으며, 고역통과필터(high pass filter)는 $3000 \mathrm{~Hz}$, 저역통과필터(low pass filter)는 $300 \mathrm{~Hz}$

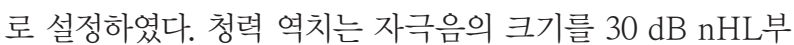
터 $90 \mathrm{~dB} \mathrm{nHL}$ 까지 $10 \mathrm{~dB} \mathrm{nHL}$ 간격으로 변화하면서 $\mathrm{V}$ 파를 관찰 할 수 있는 가장 작은 자극음의 크기로 정하였으며, $90 \mathrm{~dB}$ $\mathrm{nHL}$ 의 자극음을 주었을 때의 파형으로 잠복기(latency)와 파 간 잠복기(interatency)를 측정하였다. 청성뇌간유발반응 역치 는 $40 \mathrm{~dB} \mathrm{nHL}$ 의 음자극까지 반응을 보인 경우 통과(PASS)로 판정하였다. $50 \mathrm{~dB} \mathrm{nHL}$ 이상의 역치를 보인 경우에는, 하루 이상의 간격을 두고 재검사를 시행하여 위양성을 배제하였 으며, 재검사에서도 비정상 소견을 보인 경우를 최종적으로 비정상으로 판정하였다. 이 중 추적 검사가 가능하였던 25명을 대상으로 6 개월 이후 청성뇌간유발반응 검사를 시행하였다.

신생아 중환자실 입원 당시의 혈중 총 빌리루빈 농도의 최고 치를 조사하였고, 청성뇌간유발반응의 역치, 잠복기, 파간 잠 복기를 분석하였으며, 1 차 검사와 추적검사 간 청력역치의 변 화를 알아보았다.
청성뇌간유발반응 1 차 검사와 추적검사에서 난청 소견을 보인 환아에서 청각신경병증을 감별하기 위하여 이음향방사 검사를 시행하였다. 일과성음 유발이음향방사는 같은 검사 실에서 시행하였으며, 자극음으로는 Click음을 $1 \sim 4 \mathrm{kHz}$ 주파 수 영역을 $84 \mathrm{~dB} \mathrm{SPL}$ 의 강도로 사용하였고, 신호대 잡음비 5 $\mathrm{dB}$ 이상 또는 재현율 $50 \%$ 이상을 정상으로 판정하였다.

통계분석은 Statistical Package for the Social Sciences (SPSS) software(version 17.0 for windows, SPSS Inc., Chicago, $\mathrm{IL}, \mathrm{USA}$ )를 이용하였으며 독립표본 $\mathrm{T}$ 검정법과 일원분산분 석, Pearson 상관관계 분석을 사용하였다. 통계학적 유의 수 준은 $95 \%$ 이상 $(p<0.05)$ 으로 하였다.

\section{결 과}

총 120 명의 고빌리루빈혈증 환아 중 청성뇌간유발반응 검 사에서 정상 청력으로 확인된 환아는 59명(49.2\%)이었고, 61 명(50.8\%)의 환아에서 청력역치 $50 \mathrm{~dB} \mathrm{nHL}$ 이상의 난청으로 판정되었다. 이 중 일측성 난청으로 진단된 환아는 38 명, 양측 성 난청으로 진단된 환아는 23명이었다. 일측성 난청으로 판정 된 38 명의 환아 중 $80 \mathrm{~dB} \mathrm{nHL}$ 이상의 난청으로 진단된 환아 는 6 명이었으며, 양측성 난청으로 진단된 23명의 환아 중 양 측 모두 $80 \mathrm{~dB} \mathrm{nHL}$ 이상의 청력 역치를 보인 환아는 4 명, 한 쪽만 $80 \mathrm{~dB} \mathrm{nHL}$ 이상의 청력 역치가 확인된 환아는 2 명이었 다(Fig. 1).

청성뇌간유발반응 역치의 평균은 환자군에서 $43.8 \mathrm{~dB} \mathrm{nHL}$, 대조군에서 $30.0 \mathrm{~dB} \mathrm{nHL}$ 이었으며, 두 군의 청력 역치 평균은 통계적으로 유의한 차이를 보였다 $(p<0.01)$.

청성뇌간유발반응 잠복기의 평균은, 환자군에서 I파 1.34 $\mathrm{ms}$, III파 $3.99 \mathrm{~ms}$, V파 $6.52 \mathrm{~ms}$ 이며, 대조군에서는 I파 1.34 $\mathrm{ms}$, III파 $3.95 \mathrm{~ms}$, V파 $6.40 \mathrm{~ms}$ 로 측정되었다. 청성뇌간유

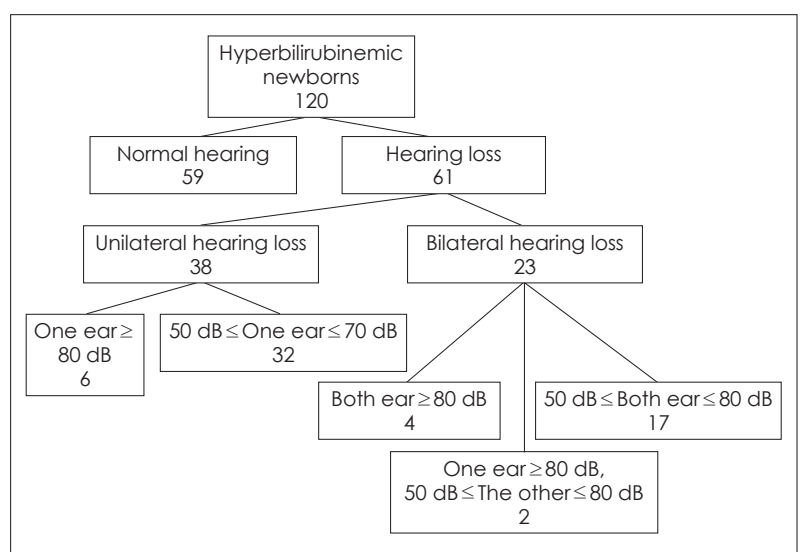

Fig. 1. Schematic view of characteristics of hearing level in hyperbilirubinemic newborns. 
Table 1. Comparison of auditory brainstem response threshold, latency and interlatency between hyperbilirubinemic newborns and normal newborns

\begin{tabular}{lcccc}
\hline & & Subject (240 ears) & Control (42 ears) & P \\
\hline ABR Threshold (dB nHL) & & 43.8 & 30 & $<0.001$ \\
Latency $(\mathrm{ms})$ & Wave I & 1.34 & 1.34 & 0.866 \\
& Wave III & 3.99 & 3.95 & 0.289 \\
& Wave V & 6.52 & 6.40 & 0.485 \\
Interlatency (ms) & I-III & 2.65 & 2.60 & 0.707 \\
& III-V & 2.52 & 2.45 & 0.264 \\
& I-V & 5.17 & 5.06 & 0.898 \\
\hline
\end{tabular}

ABR: auditory brainstem response

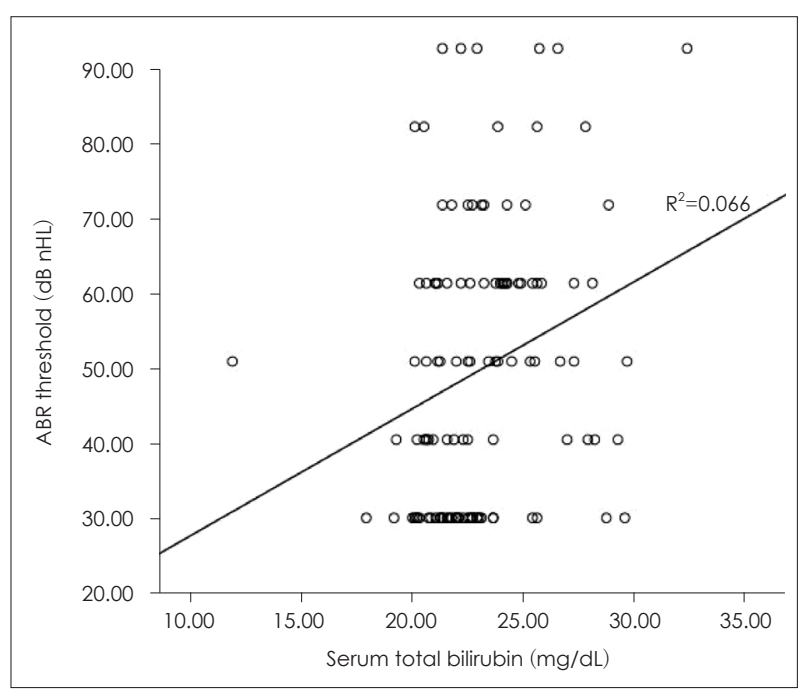

Fig. 2. Correlation between serum bilirubin and $A B R$ threshold. ABR: auditory brainstem response.

발반응의 파간 잠복기는 환자군에서 I III파간 $2.65 \mathrm{~ms}$, $\mathrm{III} \mathrm{V}$ 파간 $2.52 \mathrm{~ms}$, I V 파간 $5.17 \mathrm{~ms}$ 이며, 대조군에서는 $\mathrm{I} \sim \mathrm{III}$ 파간 $2.60 \mathrm{~ms}$, III V파간 $2.45 \mathrm{~ms}$, I V 파간 $5.06 \mathrm{~ms}$ 으 로 두 군 사이에 유의한 차이는 없었다(Table 1).

고빌리루빈혈증의 치료로는 모두 광선요법만을 사용하였 고 교환수혈을 한 환아는 없었다. 입원 당시 혈중 총 빌리루빈 농도는 $22.85 \pm 2.73 \mathrm{mg} / \mathrm{dL}$ 이었고, 광선요법을 시행하여 10.99 $\pm 2.51 \mathrm{mg} / \mathrm{dL}$ 의 호전을 보였으며, 혈중 총 빌리루빈 농도는 약 $4.59 \pm 1.21$ 일 내에 정상화 되었다. 그러나, 혈중 총 빌리루빈 농도와 청성뇌간유발반응 검사 상 난청이 있는 귀의 청력 역 치사이에는 직접적인 상관 관계를 보이지 않았다 $\left(\mathrm{R}^{2}=0.066\right)$ (Fig. 2). 고빌리루빈혈증이 지속된 기간과 청력 역치 사이의 관 계 역시 통계적 유의점은 없었다 $(p=0.84)$.

1 차 검사에서 이상소견을 보였던 고빌리루빈혈증 환아 25명 (50귀)을 대상으로 6개월 후 추적 청성뇌간유발반응 검사를 시행하였다. 이 25 명은 1 차 검사에서 일측성 난청으로 진단된 16 명과 양측성 난청 소견을 보인 9 명이었으며, 1 차 검사에서 청력 역치가 $50 \mathrm{~dB} \mathrm{nHL}$ 이상이었던 34귀 중, 24귀(70.6\%)에

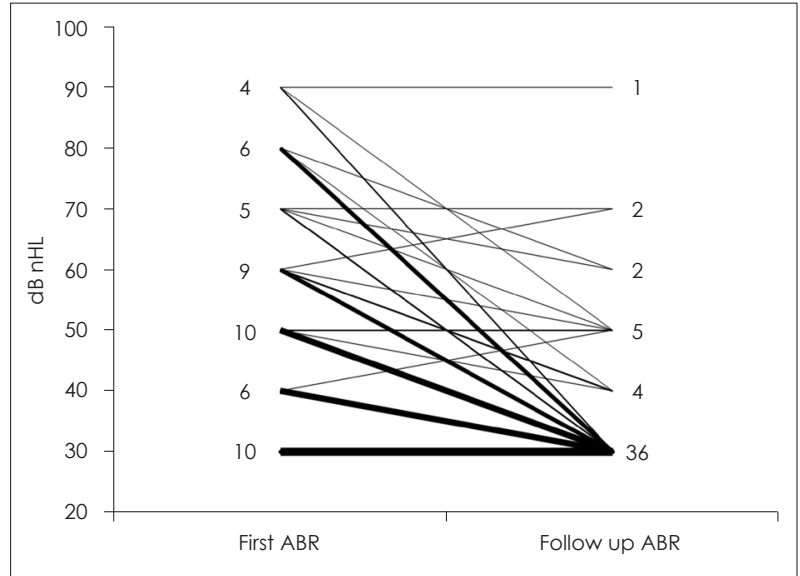

Fig. 3. ABR threshold change after 6 months later. The thickness of the line is proportional to the number of ears. Out of 36 ears over $50 \mathrm{dBn} \mathrm{HL}, 24$ ears (70.6\%) were improved to $30 \mathrm{dBn} \mathrm{HL}$. ABR: auditory brainstem response.

는 정상 청력으로 회복되었고 5 귀(14.7\%)는 부분 회복되었으 며, 이전 검사와 차이가 없거나 나빠진 경우가 5귀(14.7\%)였다. 1 차 검사에서 $40 \mathrm{~dB} \mathrm{nHL}$ 이하의 역치를 보인 16 귀는 추적검 사에서 모두 정상 소견을 보였다(Fig. 3). 추적 검사에서도 50 $\mathrm{dB} \mathrm{nHL}$ 이상의 난청이 지속된 환아는 총 8 명(10귀)이었으 며, 청각신경병증을 감별하기 위하여 8명에 대해 이음향방사 검사를 추가로 시행하였고, 이 중 1 명이 이음향방사 정상 소견 을 보여 청각신경병증으로 진단되었다.

추적 검사에서 정상 청력으로 회복된 17 명의 환아와 회복 되지 못한 8 명의 환아를 비교하였다(Table 2). 혈중 총 빌리 루빈 농도는 회복군에서 $24.22 \pm 3.25 \mathrm{mg} / \mathrm{dL}$, 비회복군에서 $21.32 \pm 1.01 \mathrm{mg} / \mathrm{dL}$ 로 오히려 회복군에서 높은 수치를 보였으 나, 통계적 유의점은 없었다. 광선요법 기간은 회복군에서 4.86 \pm 2.18 일, 비회복군에서 $4.50 \pm 1.38$ 일로 큰 차이는 없었다. 청성 뇌간유발반응 역치는 회복군이 $64.12 \mathrm{~dB} \mathrm{nHL}$ 에서 $32.35 \mathrm{~dB}$ $\mathrm{nHL}$ 로 호전되었고, 비회복군과 비교하여 통계적으로 유의하 였다 $(p<0.05)$. 그 외 I, III, V파의 잠복기와 I III, III V, I V V 파간 잠복기 등은 두 군에서 유의한 차이를 보이지 않았다. 
ABR in Newborns with Hyperbilirubinemia I Cho YH, et al.

Table 2. Comparison between recovered group and not recovered group

\begin{tabular}{|c|c|c|c|c|c|}
\hline & & \multicolumn{2}{|c|}{ Recovered group (17 newborns) } & \multicolumn{2}{|c|}{ Not recovered group (8 newborns) } \\
\hline Serum bilirubin ( $m$ & & \multicolumn{2}{|c|}{$24.22 \pm 3.25$} & \multicolumn{2}{|c|}{$21.32 \pm 1.01$} \\
\hline \multicolumn{2}{|c|}{ Phototherapy (day) } & \multicolumn{2}{|c|}{$4.86 \pm 2.18$} & \multicolumn{2}{|c|}{$4.50 \pm 1.38$} \\
\hline & & Initial & Follow up & Initial & Follow up \\
\hline \multicolumn{2}{|c|}{ ABR threshold $(\mathrm{dB} n \mathrm{~nL})^{*}$} & 64.12 & 32.35 & 70.00 & 60.00 \\
\hline \multirow[t]{3}{*}{ Latency (ms) } & Wave I & 1.49 & 1.31 & 1.33 & 1.37 \\
\hline & Wave III & 4.13 & 3.68 & 3.95 & 3.61 \\
\hline & Wave V & 6.69 & 5.98 & 6.59 & 6.09 \\
\hline \multirow[t]{3}{*}{ Interlatency (ms) } & $|-1| \mid$ & 2.65 & 2.37 & 2.62 & 2.24 \\
\hline & $\| I I-V$ & 2.55 & 2.30 & 2.63 & 2.48 \\
\hline & $\mathrm{I}-\mathrm{V}$ & 5.20 & 4.67 & 5.26 & 4.72 \\
\hline
\end{tabular}

$* p<0.05$

\section{고 찰}

신생아 난청은 선천성 질환 중 비교적 발병률이 높은 질환의 하나로, ${ }^{1,2}$ 중등도 이상의 신생아 난청은 언어 습득과 발달지 연으로 이어지며, 사회활동과 학습능력의 장애를 일으켜 사회 경제적인 부담으로 연결된다. ${ }^{9)}$ 생후 6 개월 이내의 소리자극은 언어발달에 매우 중요하기 때문에, 조기에 난청을 진단하고 청 각재활이 필요한 신생아를 선별하여 관리와 치료를 시행하는 것이 필요하다. ${ }^{10-12)}$

일반적으로, 난청 가족력, 주산기 감염, 두개안면기형, 저체 중, 고빌리루빈혈증, 이독성 약물, 세균성 수막염, 낮은 Apgar 점수, 5 일 이상의 기계 환기, 다른 동반 증후군 등이 난청의 위 험인자로 알려져 있다. ${ }^{13,14)}$ 2007년에 발표된 Joint Committee on Infant Hearing(JCIH) 성명서에 따르면, 모든 신생아는 생 후 1 개월 안에 청력 선별검사를 시행받아야 하며, 선별검사를 통과하지 못한 신생아들은 생후 3 개월 안에 확진 검사를 통해 난청을 진단받아야 하고, 확진 검사를 통해 신생아 난청으로 진단된 환아들은 생후 6 개월 이전에 난청에 대한 조기 중재를 받을 수 있도록 해야 한다고 권고하였다. ${ }^{2)}$ 또한 5일 이상 신생 아 중환자실에 입원한 신생아들은 청성뇌간유발반응 검사를 선별검사로 시행하도록 권고하였고, 이에 따라 신생아 중환자 실 환아의 청각 선별검사로써 청성뇌간유발반응 검사를 시행 하고 있다. ${ }^{15)}$ 청성뇌간유발반응 검사는 감수성과 특이성이 높 고, 비침습적으로 신생아에게 적용이 용이하다. 신생아의 경우 I, III, V파만 기록되고, 정상 성인에 비해 잠복기가 길게 나타 날 수 있다. ${ }^{16)}$ 최근 많이 시행되고 있는 자동화 청성뇌간유발 반응 검사는 검사 시간이 짧고, 비용이 저렴한 장점이 있어 선 별검사로써 많이 사용되고 있다. ${ }^{8)}$

고빌리루빈혈증은 신생아 중환자실에 입원이 필요한 가장 흔 한 신생아기 질환 중 하나이다. 빌리루빈은 미토콘드리아 효소 와 DNA 합성을 억제하여 신경의 흥분성 신호 전달을 방해하
는 일종의 신경독성물질로 알려져 있으며, 비포합 빌리루빈(unconjugated bilirubin)은 뇌-혈관장벽을 통과할 수 있다. ${ }^{17,18)}$ 빌리루빈의 영향으로 와우핵이 손상되며, 청신경 및 기저핵에 빌리루빈이 축적된다는 보고가 있으나 빌리루빈에 의한 와우 및 청신경의 손상기전은 확실하게 밝혀지지는 않았다. ${ }^{19)}$ 고빌 리루빈혈증으로 인해 발생하는 난청의 경우, 청신경 또는 뇌 간의 병변이 난청의 원인인 경우가 대부분이며, 와우는 정상 인 경우가 많다. ${ }^{1920)}$ 이와 같이 일부 감각신경성 난청 환자에서 이음향방사는 나타나지만 청성뇌간유발반응은 나타나지 않 는 경우를 청각신경병증으로 분류하고 있다. ${ }^{7)}$ 청각신경병증 의 병태생리는 확실히 밝혀진 바 없으나, 청신경 자체의 문제, 청신경과 내유모 세포 사이의 연결 이상으로 기인하는 것으로 알려져 있다. 청각신경병증 발병의 위험인자로는 고빌리루빈 혈증, 저산소증, 이독성약물, 가족력, 주산기 감염 등이다. 청각 신경병증의 위험 인자를 가진 환아들의 청력검사로는 이음향 방사 검사보다는 청성뇌간유발반응검사를 시행하는 것이 청력 평가에 도움이 된다. ${ }^{8,10}$

고빌리루빈혈증과 관련한 신생아 난청은 혈중 총 빌리루빈 농도와 관련이 있는 것으로 알려져 있다. $6,17,18)$ 그러나, 본 연구 에서는 혈중 총 빌리루빈 농도와 청성뇌간유발반응 역치 사이 의 직접적인 상관 관계는 보이지 않았다. 이는, 환자군의 혈중 총 빌리루빈 농도가 $22.85 \pm 2.73 \mathrm{mg} / \mathrm{dL}$ 로 비교적 높지 않았으

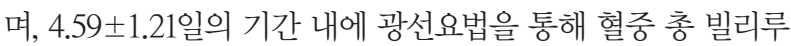
빈 농도가 정상화 되었고, 교환수혈을 시행하거나, 핵황달이 발생할 정도의 심한 사례는 없었기 때문으로 판단된다. 그러 나, 환자군과 대조군의 청력 역치 차이는 통계적으로 유의하 였기에, 이를 통하여 고빌리루빈혈증의 유무가 난청과 관계가 있음을 유추할 수 있다.

광선요법, 교환수혈 등의 내과적 치료를 통하여 혈중 총 빌 리루빈 농도가 정상화되면, 뇌간의 기능이 회복될 수 있고 이 를 바탕으로 청력회복을 기대할 수 있다. ${ }^{13,20)}$ 본 연구에서도 
청성뇌간유발반응의 추적 검사가 가능하였던 환아의 대부분 에서 고빌리루빈혈증이 치료되면서 청력 역치가 호전된 것을 확인하였으며, 이를 바탕으로 고빌리루빈혈증에 의한 난청은 대부분 가역적이라 생각할 수 있다. 그러나 추적검사에서도 지속적인 난청을 보이는 경우가 확인되었고, 일부에서는 청각 신경병증으로 진단된 것으로 미루어 볼 때 고빌리루빈혈증 환 아에서는 연속적인 청성뇌간유발반응 검사로 지속되는 난청 을 정확히 진단할 수 있어야 한다.

$2007 \mathrm{JCIH}$ 성명서에 따라, 신생아 중환자실에 5일 이상 입 원한 환아에 대해서 선별검사로써 자동화 청성뇌간유발반응 검사를 시행 후 의뢰(refer)된 환아에 대해서는 진단적 청성뇌 간유발반응 검사를 권장하고 있다. 신생아 청력 선별검사로 써 이음향방사와 청성뇌간유발반응을 비교한 타 연구에서도 전체 신생아 수의 10 16\%를 차지하는 신생아 중환자실 환아 에 대해서는 청성뇌간유발반응 검사가 상대적으로 시간이 많 이 걸리나, 선별검사로써 유용할 것이라 하였다. ${ }^{6.8)}$ 본 후향적 연구의 대상환자에서는 일차적으로 모두 진단적 청성뇌간유 발반응이 시행되었고, 이음향방사 검사는 동시에 시행되지 않 았으며, 추적 청성뇌간유발반응 검사에서도 난청 소견을 보이 는 환아에 대해서만 청각신경병증을 감별하기 위해 이음향방 사 검사를 시행하였다. 그러나, 일차검사에서 청성뇌간유발반 응 검사와 이음향방사 검사를 함께 시행하였거나, 일차검사에 서 난청 소견을 보였던 61 명의 환아에 대해 이음향방사 검사를 시행하였다면 고빌리루빈 환아에서 난청양상과 두 검사의 결 과를 비교하는 데 도움을 얻었을 것으로 생각된다.

청성뇌간유발반응 검사의 잠복기 및 파간 잠복기는 고빌리 루빈환아에서 대조군에 비해 III파, V파의 잠복기가 증가된 것을 확인 할 수 있었으나 통계적으로 유의하지는 않았다. 이 를 바탕으로 빌리루빈이 기존에 알려진 바와 유사하게 청신경 혹은 기저핵 등의 청각경로에 주로 작용 할 것이라 생각해 볼 수 있으나, 이에 대한 추가적인 연구가 뒷받침 되어야 할 것이다.

\section{REFERENCES}

1) Lim HW, Han MW, Lee HS, Kim KS, Chung JW, Kim YJ, et al. The validity using two-stage automated auditory brainstem response as a universal newborn hearing screening protocol: experiences in Asan Medical Center. Korean J Otolaryngol 2007;50(2):108-14.

2) Erenberg A, Lemons J, Sia C, Trunkel D, Ziring P. Newborn and infant hearing loss: detection and intervention. American Academy of Pediatrics. Task Force on Newborn and Infant Hearing, 1998-1999. Pediatrics 1999;103(2):527-30.
3) Chang SO, Choi BY, Hwang CH, Ahn SH, Lee MC, Oh SH, et al. The efficacy of the hearing threshold level at $3 \mathrm{kHz} \mathrm{I} / \mathrm{O}$ curve in DPOAE in screening the high risk neonates in NICU. Korean J OtolaryngolHead Neck Surg 2002;45(4):322-7.

4) Berlin CI, Hood L, Rose K. On renaming auditory neuropathy as auditory dys-synchrony. Audiology Today 2001;13:15-7.

5) Berlin CI, Morlet T, Hood LJ. Auditory neuropathy/dyssynchrony: its diagnosis and management. Pediatr Clin North Am 2003;50(2): 331-40, vii-viii.

6) Rhee CK, Park HM, Jang YJ. Audiologic evaluation of neonates with severe hyperbilirubinemia using transiently evoked otoacoustic emissions and auditory brainstem responses. Laryngoscope 1999; 109(12):2005-8.

7) Saluja S, Agarwal A, Kler N, Amin S. Auditory neuropathy spectrum disorder in late preterm and term infants with severe jaundice. Int $\mathrm{J}$ Pediatr Otorhinolaryngol 2010;74(11):1292-7.

8) Choi BY, Lee MC, Oh SH, Kim CS, Choi JH, Chang SO. The efficacy of automated distortion product otoacoustic emission and automated auditory brainstem response in universal hearing screening. Korean J Otolaryngol 2004;47(1):27-32.

9) Kim LS, Jeong SW. Hearing threshold prediction using auditory brainstem response and auditory steady-state response in infants and young children. Korean J Otorhinolaryngol-Head Neck Surg 2011;54(9):592-602.

10) Chang SO, Oh SJ, Koo JW, Lim D, Hwang CH, Kim CS, et al. Distortion product and spontaneous otoacoustic emissions in normal neonates. Korean J Otolaryngol 2000;43(4):363-8.

11) Moon SK, Park HJ, Kim Y, Park MS, Choung YH, Park K. Results and cost-effectiveness of newborn hearing screening program in Ajou University Hospital. Korean J Otolaryngol 2002;45(11):1052-6.

12) Lim HW, Kim EA, Chung JW. Audiological Follow-up Results after Newborn Hearing Screening Program. Clin Exp Otorhinolaryngol 2012;5(2):57-61.

13) Shapiro SM, Popelka GR. Auditory impairment in infants at risk for bilirubin-induced neurologic dysfunction. Semin Perinatol 2011; 35(3):162-70.

14) Kountakis SE, Skoulas I, Phillips D, Chang CY. Risk factors for hearing loss in neonates: a prospective study. Am J Otolaryngol 2002; 23(3):133-7.

15) American Academy of Pediatrics, Joint Committee on Infant Hearing. Year 2007 position statement: principles and guidelines for early hearing detection and intervention programs. Pediatrics 2007; 120(4):898-921.

16) Wilkinson AR, Jiang ZD. Brainstem auditory evoked response in neonatal neurology. Semin Fetal Neonatal Med 2006;11(6):444-51.

17) Ye HB, Shi HB, Wang J, Ding DL, Yu DZ, Chen ZN, et al. Bilirubin induces auditory neuropathy in neonatal guinea pigs via auditory nerve fiber damage. J Neurosci Res 2012;90(11):2201-13.

18) Jiang ZD, Wilkinson AR. Impaired function of the auditory brainstem in term neonates with hyperbilirubinemia. Brain Dev 2013. [Epub ahead of print]

19) Shapiro SM. Bilirubin toxicity in the developing nervous system. Pediatr Neurol 2003;29(5):410-21.

20) Moon SK, Park HJ, Park MS, Kang YS, Kim Y, Choung YH, et al. Clinical follow-up of hearing-impaired infants detected by newborn hearing screening. Korean J Otolaryngol 2004;47(9):812-7. 